\title{
Hot-water drilling at Glaciar Perito Moreno, Southern Patagonia Icefield
}

\section{Shin SUgIYAMA ${ }^{1}$, Pedro SKVARCA ${ }^{2}$, Nozomu NAITO ${ }^{3}$, Kenta TONE ${ }^{1}$, Hiroyuki ENOMOTO ${ }^{4}$, Kunio SHINBORI ${ }^{1}$, Sebastian MARINSEK ${ }^{2}$ and Masamu ANIYA ${ }^{5}$}

1 Institute of Low Temperature Science, Hokkaido University, Nishi-8 Kita-19 Sapporo, 060-0819 Japan

2 Dirección Nacional del Antártico-Instituto Antártico Argentino, Cerrito 1248, Buenos Aires, Argentina

3 Department of Global Environment Studies, Hiroshima Institute of Technology, 2-1-1, Miyake, Saeki-ku, Hiroshima, 731-5193

Japan

4 Department of Civil Engineering, Kitami Institute of Technology, 165, Koen-cho, Kitami, 090-8507 Japan

5 Professor Emeritus, University of Tsukuba, Tsukuba, 305-8572 Japan

(Received November 10, 2010; Revised manuscript accepted December 3, 2010)

\begin{abstract}
Glaciar Perito Moreno is one of the major freshwater calving glaciers in the Southern Patagonia Icefield. Its fast-flowing characteristic is probably due to high water pressure at the glacier bed, however, subglacial conditions have never been observed in Patagonia until our recent undertaking. To investigate the role of subglacial water pressure in the calving glacier dynamics, we performed hot-water drilling at Glaciar Perito Moreno from February to March 2010. This study represents the first attempt ever at hot-water glacier drilling in Patagonia. Two boreholes were drilled to the bed at $4.7 \mathrm{~km}$ upglacier from the terminus, where the ice was revealed to be $515 \pm 5 \mathrm{~m}$ thick and the bed located at about $330 \mathrm{~m}$ below the proglacial lake level. The water levels in the boreholes were $>100 \mathrm{~m}$ above the lake level, which indicates that more than $90 \%$ of the ice overburden pressure was balanced out by the subglacial water pressure. Water in the boreholes had drained away before the drilling reached the bed, suggesting the existence of an englacial drainage system. These results provide crucial information for understanding the hydraulic and hydrological conditions of calving glaciers. In order to drill a $500 \mathrm{~m}$ deep glacier, an existing hot-water drilling system was adapted by increasing the number of high-pressure hot-water machines. The drilling operation at Glaciar Perito Moreno confirmed the system's capacity to drill a 500-m-deep borehole at a rate of $50 \mathrm{~m} \mathrm{~h}^{-1}$ with fuel consumption rates of $15.71 \mathrm{~h}^{-1}$ for diesel and $3.91 \mathrm{~h}^{-1}$ for petrol.
\end{abstract}

Key words: calving glacier, hot water drilling, subglacial water pressure, borehole, Patagonia

\section{Introduction}

The close examination of physical conditions beneath a glacier (e.g., water pressure, drainage system, unconsolidated sediment layer, bedrock roughness) is important for understanding the role of basal processes in glacier motion. Subglacial conditions determine the speed of ice sliding over a bedrock as well as the deformation of a subglacial sediment layer, causing substantial changes in glacier flow speed. These basal ice flow processes are particularly important in outlet glaciers in Patagonia Icefields since most of them terminate in lakes or the ocean (Warren and Aniya, 1999; Rignot et al., 2003; Rivera et al., 2007). Calving glaciers flow faster than land terminating glaciers, particularly because the basal flow processes are enhanced by high water pressure generated by the proglacial water body. Since a large amount of ice is discharged from the fast-flowing calving glaciers in Patagonia (Naruse et al., 1992; Skvarca et al., 1995; Warren et al., 1995a; Warren et al., 1995b; Rott et al., 1998), the dynamics of these glaciers plays a key role in the recent ice mass loss of the Patagonia Icefields (Aniya et al., 1997; Aniya, 1999; Rignot et al., 2003; Rivera et al., 2007). Nevertheless, detailed studies on glacier dynamics are very scarce and subglacial measurements have never been carried out in Patagonia.

Glaciar Perito Moreno is a fast-flowing freshwater calving glacier in Patagonia. The glacier extends over $30 \mathrm{~km}$ to the northeast from the Southern Patagonia Icefield and covers an area of $258 \mathrm{~km}^{2}$ (Aniya et al., 1997). The glacier front currently terminates in Brazo Rico and Canal de los Témpanos (185 m a.s.1.) (Stuefer et al., 2007), forming a narrow water channel between the glacier snout and Península Magallanes. (Fig. 1a). 


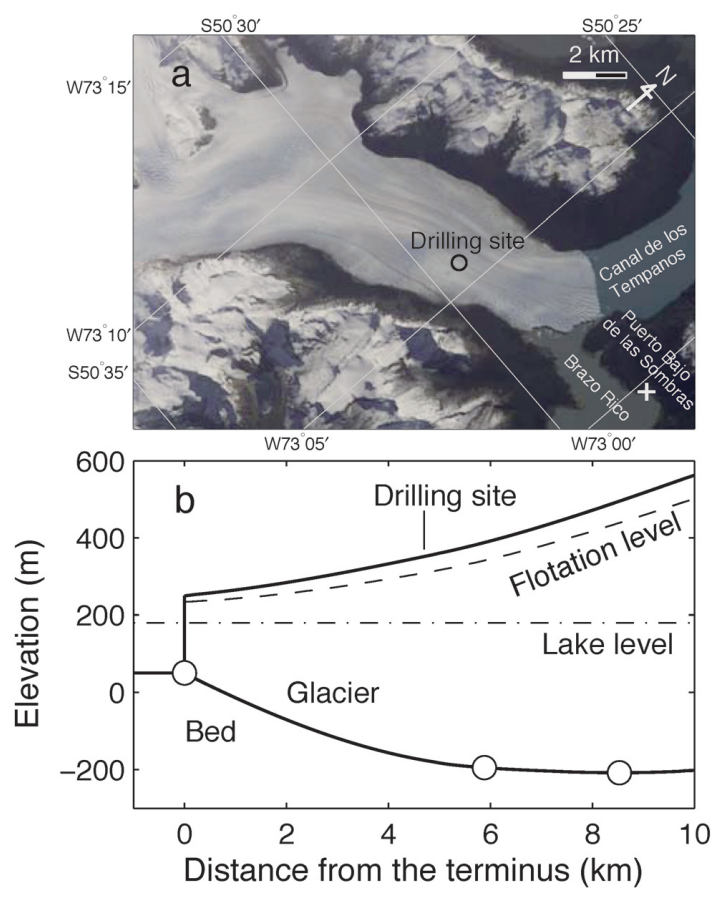

Figure 1. (a) Satellite image of Glaciar Perito Moreno with the drilling site indicated by $(\bigcirc)$. Drilling equipment was transported by a helicopter from the site indicated by $(+)$. The image was taken on 27 March 2002 (image courtesy of the Image Science \& Analysis Laboratory, NASA Johnson Space Center). (b) Longitudinal cross section of Glaciar Perito Moreno along the central flowline. The bed profile is drawn by interpolation of observational data points (O) (Stuefer et al., 2007). The lake water level and ice flotation level are indicated by the dot-dashed and dotted lines.

Unlike the other glaciers in Patagonia, no significant retreat is being observed in Glaciar Perito Moreno (Aniya and Skvarca, 1992; Skvarca and Naruse, 1997; Stuefer, 1999; Stuefer et al., 2007). Its front position has oscillated within several hundred meters since the early 20th century (Skvarca and Naruse, 1997). The glacier flows at a rate of $400-800 \mathrm{~m} \mathrm{a}^{-1}$ in the region extending several kilometers from the calving front (Rott et al., 1998; Michel and Rignot, 1999; Floricioiu et al., 2008; Ciappa et al., 2010). According to seismic soundings performed by Stuefer et al. (2007), the glacier bed elevation is $150-400 \mathrm{~m}$ below the lake level within the reach of $10 \mathrm{~km}$ from the terminus (Fig. 1b). The glacier bed is thus expected to be at high water pressure under the influence of the proglacial lakes. A substantial part of ice overburden pressure is balanced out by the subglacial water pressure, which is a preferable condition for the basal ice flow processes (e.g., Bindschadler, 1983). Annual flow speed variations are relatively small (Stuefer et al., 2007), whereas a clear seasonal flow speed change has been observed by a recent study using satellite data (Ciappa et al., 2010). Naruse et al. (1995) reported diurnal flow speed variations at a few hundred meters from the side margins.

In the 2008/2009 austral summer season, we carried out high-frequency ice flow measurements on Glaciar Perito Moreno and found clear diurnal flow speed variations in the central region of the glacier at about $5 \mathrm{~km}$ from the terminus (Sugiyama et al., 2009). The flow speed was closely correlated to air temperature, suggesting that meltwater production is controlling the basal ice flow by swiftly changing subglacial water pressure. The flow speed was very sensitive to the meltwater input, probably because the relationship between the water pressure and flow speed is highly nonlinear when the pressure rises close to the overburden pressure (Bindschadler, 1983; Truffer and Iken, 1998; Sugiyama and Gudmundsson, 2004). To test this hypothesis, we drilled Glaciar Perito Moreno using a hot-water drilling technique to measure subglacial water pressure. This was the first attempt in Patagonia to drill through a glacier for the purpose of conducting subglacial observations. The aim of this paper is to describe the hot-water drilling system used for this project and report the drilling field campaign carried out in early 2010.

\section{Hot-water Drilling System}

The hot-water drilling system was prepared by adapting an existing system developed at the Institute of Low Temperature Science, Hokkaido University (Sugiyama et al., 2008; Tsutaki and Sugiyama, 2009). The original system was designed for drilling as deep as $200 \mathrm{~m}$, thus it was necessary to increase the drilling capacity to drill through Glaciar Perito Moreno with expected thickness of 450-550 m at our study site. We installed an additional high-pressure hot-water machine (Kärcher HDS1000BE) and constructed piping to bring together hot water from two machines (Fig. 2a). The length of the drilling hose was extended to $550 \mathrm{~m}$. An electrically powered winch system (Fig. 2b) was developed to lower down and lift up the hose in a borehole, as the hose is too heavy to handle by man power alone during deep drilling. The winch was controlled by hand using a handle connected to a gear system as observed in Figure $2 \mathrm{~b}$. Electric power from a generator was used only to wind up the hose after the completion of drilling. The winch was equipped with a brake system (lower right in Fig. 2b) designed and constructed at the workshop of the Institute of Low Temperature Science. This brake keeps the hose tightly wound around the winch drum, so that the necessary friction was generated at the interface between hose and drum.

The hot water machines draw water with petroldriven pumps from a water basin or supraglacial water source. The water is warmed up with a heater which uses diesel as fuel. Hot water flowed through $12.7 \mathrm{~mm}$ inner diameter high pressure hoses (Bridges- 


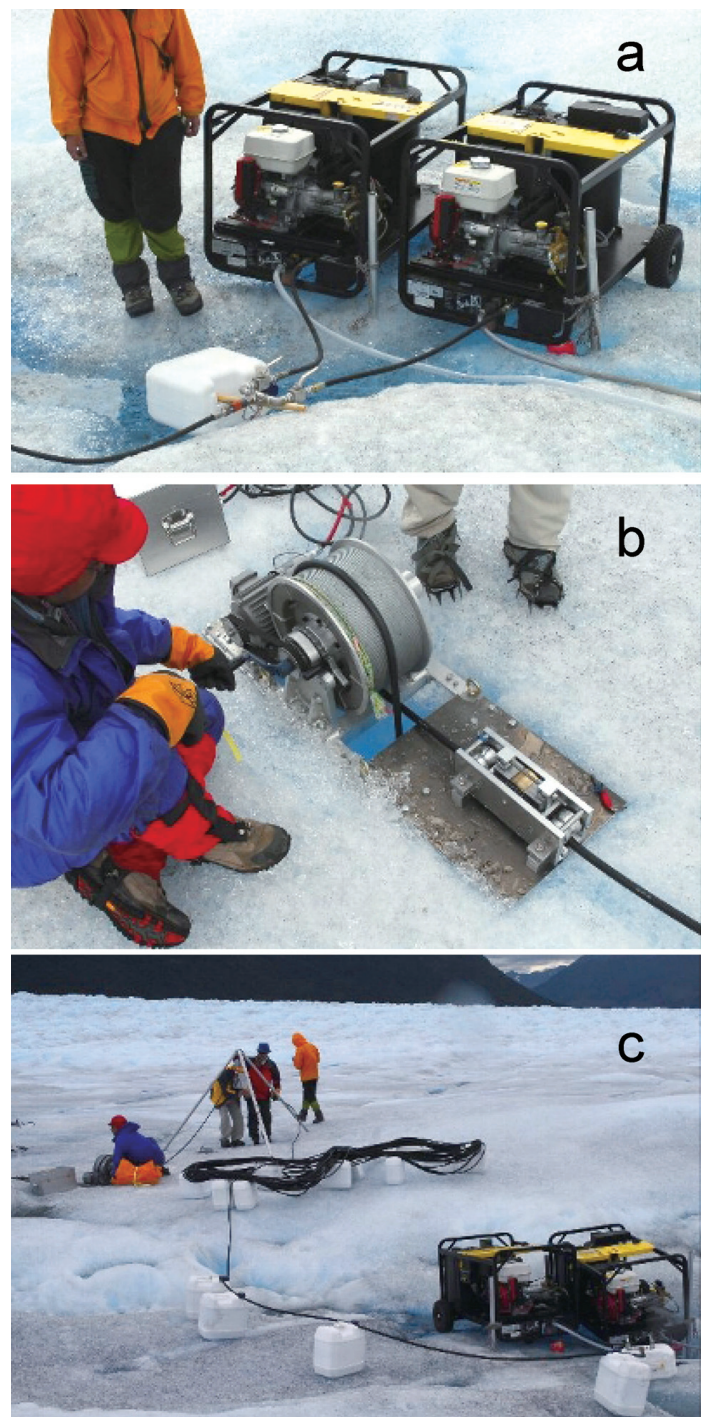

Figure 2. Photographs showing hot-water drilling on Glaciar Perito Moreno. (a) High-pressure hot-water machines. The machines discharge hot water through the black hoses, which are combined into one by means of the piping. (b) Winch system with a brake in the lower right. (c) The hot-water drilling system set up on the glacier. The borehole is at the middle left.

tone WAR08, outer diameter is $19.8 \mathrm{~mm}$ ) before it emitted a narrow water jet from a $3.0 \mathrm{~mm}$ diameter nozzle (Katorigumi Inc. K-18). The nozzle was mounted on a 3-m-long metal pipe, which provided a load to straighten the hanging hoses for drilling a vertical borehole. For drilling of shallow boreholes, a tripod and pulley system was used instead of the winch. The weight of all the drilling equipment was approximately $600 \mathrm{~kg}$, excluding fuel.

The drilling system was tested before the campaign at the Institute of Low Temperature Science using a water basin filled with water from a tap. The temperature of the water jet was measured with a temperature logger (HIOKI 3633) following a method described in Tsutaki and Sugiyama (2009). The system generated hot water at about $65^{\circ} \mathrm{C}$ at a rate of 1600

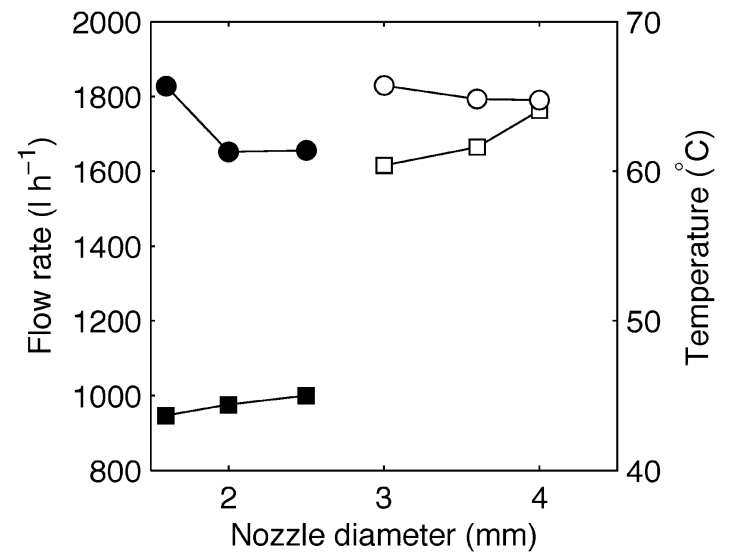

Figure 3. Flow rate $(\bigcirc)$ and water jet temperature $(\square)$ of the hot-water drilling system obtained using water jet nozzles with different diameters. The closed circles and squares $(\boldsymbol{\bullet}, \boldsymbol{\square})$ are flow rate and temperature reported for the old system, which uses one hot-water machine (Tsutaki and Sugiyama, 2009).

$1 \mathrm{hr}^{-1}$ and a pressure of $10 \mathrm{MPa}$ (Fig. 3). The water temperature and the flow rate show that the new system generates approximately $80 \%$ more power (heat in a unit time) than the original system (Fig. 3) (Tsutaki and Sugiyama, 2009).

\section{Overview of Field Campaign}

The field campaign began on 24 February 2010. It was ascertained that the location of the drilling site fulfilled the requisite conditions such as: availability of water, relatively flat surface for drilling and helicopter operations, proximity to the 2008/09 GPS measurement sites, and ice thickness not greater than the hose length. After a reconnaissance visit on 24 February, the drilling site was chosen at $550^{\circ} 29^{\prime} 27.2^{\prime \prime}$, W73 ${ }^{\circ} 5^{\prime}$ 39.5" (Fig. 1a). The site was $4.7 \mathrm{~km}$ from the terminus and several hundred meters off the central flowline. The ice thickness was estimated as $450-550 \mathrm{~m}$, based on the seismic data (Stuefer et al., 2007). Water was available in a nearby supraglacial pond. The drilling equipment and fuel (4001 of diesel for the heaters and 1501 of petrol for the pumps and generator) were transported on 25 February by a helicopter of the Gendarmería Nacional from Puerto Bajo de las Sombras located at $7.5 \mathrm{~km}$ east of the drilling site (Fig. 1a). The system was set up immediately upon arrival at the site, and drilling began on 26 February. As the drilling site was a two-hour walk from our camp, the daily activity on the glacier was limited to $1000-1900 \mathrm{~h}$. Drilling operations continued until March 5 and the equipment was evacuated by helicopter from the glacier on the following day. 


\section{Drilling}

Drilling did not progress efficiently until 28 February because one of the pumps needed to be repaired and the winch system had to be tested. The first borehole (BH1) reached the glacier bed on 2 March after the consumption of 2351 of diesel and 901 of petrol. The total duration of the hot-water system operation was 21 hours, including time spent for testing the devices. The total fuel consumption rates were $11.21 \mathrm{~h}^{-1}$ for diesel and $4.31 \mathrm{~h}^{-1}$ for petrol. The diesel consumption rate was lower than the normal value of the system because one of the two hot water machines was out of order during the first half of the drilling. The second borehole (BH2) was drilled approximately $5 \mathrm{~m}$ downglacier from BH1. Drilling began on 4 March and completed the next day after 10.5 hours of operation. The diesel and petrol consumption rates were 15.7 and $3.91 \mathrm{~h}^{-1}$, respectively.

Figure 4 shows drilling depth as a function of drilling duration. The depth was known from the hose length plus its extension due to the own weight. The extension was calculated from the extension rate $\left(7.1 \times 10^{-5} \mathrm{~N}^{-1}\right)$ and hose weight $\left(0.25 \mathrm{~kg} \mathrm{~m}^{-1}\right)$ reported by the manufacturer (Bridgestone Co.). The drilling rate for BH1 was not uniform because we began drilling by hand with the tripod and pulley system and then the system was replaced by the winch at the depth of $197 \mathrm{~m}$. Hand drilling is generally more efficient unless the hose in a borehole is too heavy to handle. The winch system was used for the entire part of $\mathrm{BH} 2$ to avoid an interruption due to the exchange of the systems. Drilling rates from the surface to the bed were 48 and $50 \mathrm{~m} \mathrm{~h}^{-1}$ for $\mathrm{BH} 1$ and $\mathrm{BH} 2$, respectively. The drilling speed and fuel consumption rates are summarized in Table 1.

In order to detect the glacier bed during drilling, the weight of the drilling hose hanging in the borehole was measured every 5 to $20 \mathrm{~m}$ (Fig. 5). A rope was twisted around the hose to hang it under a hook of a spring scale. Sudden increases in the load were observed at hose lengths of $344 \mathrm{~m}$ in $\mathrm{BH} 1$ and $375 \mathrm{~m}$ in $\mathrm{BH} 2$. These clear changes occurred because of water drainage from the borehole as described later in this section. At hose lengths between 506-512 m (BH1) and 504-512 $\mathrm{m}$ (BH2), the load suddenly dropped and decreased progressively as we continued the drilling. Detailed measurements in BH1 showed that the change could be reproduced by lowering and lifting the hose at this depth (Fig. 5 inset). These were clear indications that the drilling nozzle hit the bed. The load decreased because the nozzle came into contact with the bed and the hose leaned on the borehole wall. Based on these observations, we conclude that the ice thickness at the drilling site was $504-512 \mathrm{~m}$ plus stretching of the hose $(7 \pm 0.5 \mathrm{~m})$ and ambiguities in the hose

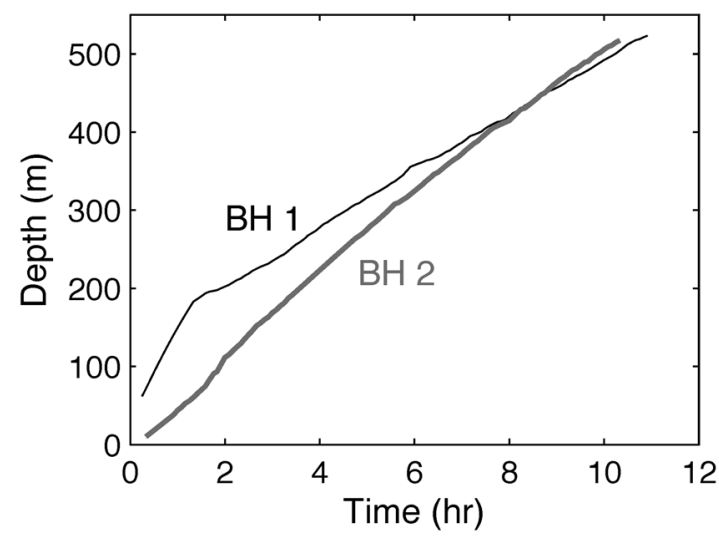

Figure 4. Drilling depth v.s. duration for the drilling of BH1 (black) and BH2 (bold gray).

Table 1. Depth of the boreholes, drilling speed and fuel consumption rates of the hot water system.

\begin{tabular}{|c|c|c|c|c|}
\hline \multirow[t]{2}{*}{ Borehole } & \multirow{2}{*}{$\begin{array}{c}\text { Depth } \\
\text { m }\end{array}$} & \multirow{2}{*}{$\begin{array}{l}\text { Drilling speed } \\
\qquad \mathrm{m} \mathrm{h}^{-1}\end{array}$} & \multicolumn{2}{|c|}{ Fuel consumption rate } \\
\hline & & & Diesel $\left(1 \mathrm{~h}^{-1}\right)$ & Petrol $\left(\mathrm{l} \mathrm{h}^{-1}\right)$ \\
\hline BH1 & $516 \pm 4$ & 48 & 11.2 & 4.3 \\
\hline $\mathrm{BH} 2$ & $515 \pm 5$ & 50 & 15.7 & 3.9 \\
\hline
\end{tabular}

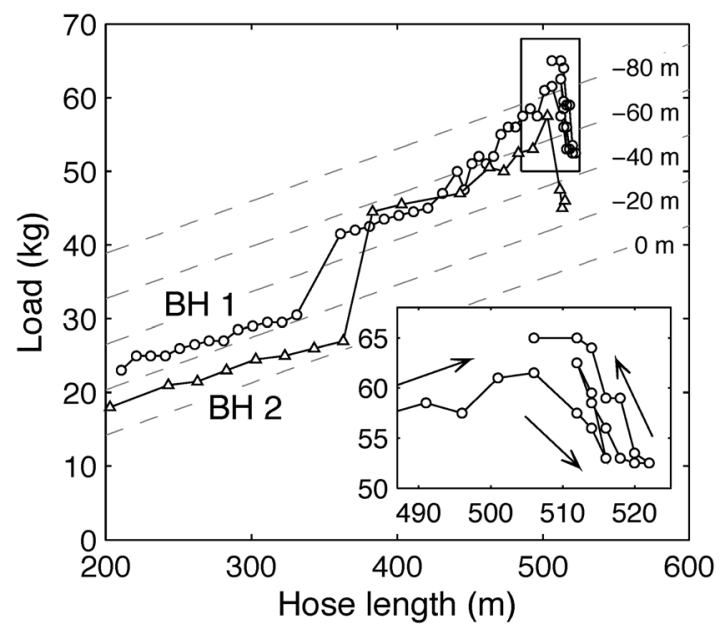

Figure 5. Weight of the drilling hose measured during the drilling of $\mathrm{BH} 1(\bigcirc)$ and $\mathrm{BH} 2(\triangle)$. The dashed lines are weight of the hose estimated for the indicated water levels (relative to the surface). The inset shows details near the bed in BH1.

length ( \pm 0.5 ), which equals to $515 \pm 5 \mathrm{~m}$. This result is consistent with the seismic data (Stuefer et al., 2007), although detailed comparison is not possible as the seismic measurements were performed several hundred meters upglacier from our drilling site.

Boreholes are usually filled with water during hot-water drilling. The water often drains away when a borehole reaches the bed, but drainage can also occur beforehand, within the glacier. These drainage events provide important information on subglacial and englacial hydrological connections. Water in BH1 first drained at $176 \mathrm{~m}$ from the surface. 

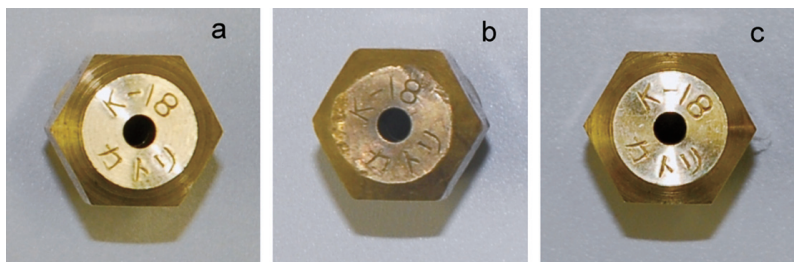

Figure 6. Drilling nozzles (a) before the drilling and (b) after the drilling of $\mathrm{BH} 1$ and (c) $\mathrm{BH}$.

The sudden increase in the hose weight at the depth $344 \mathrm{~m}$ (Fig. 5) implies that water drained again and buoyancy force acting on the hose decreased. Judging from the weight of the hose hanging in the borehole estimated for different water levels (dashed lines in Fig. 5), the level dropped from 20 to $50 \mathrm{~m}$ below the ice surface at the second drainage. In $\mathrm{BH} 2$, drainage occurred at $375 \mathrm{~m}$ depth, as did the increase in weight (Fig. 5). The change in the weight by $17.5 \mathrm{~kg}$ implies that the water level dropped approximately $60 \mathrm{~m}$. These observations suggest the existence of an englacial drainage system in Glaciar Perito Moreno. According to our visual observation of the water level in the boreholes, the drainage rate was in the range of $10^{-2}-10^{-1} \mathrm{~m}^{3} \mathrm{~min}^{-1}$. This rate was relatively lower than those of subglacial and englacial drainage that we encountered in the Alps.

The inspection of the hot-water jet nozzles after the drilling provided a clue to glacier bed conditions. The surface of the brass nozzle often became heavily scratched or scraped when it hit bedrock (Sugiyama et al., 2008). However, the nozzle used for BH1 had only small scratch marks and the one used in BH2 bore no evidence of contact with rocks (Figure 6). Therefore, it is likely that the glacier is underlain by an unconsolidated layer composed of sediment and gravels at the drilling site. The difference in the damage to the nozzles used in the two boreholes may be due to the fact that we moved the drill up and down at the bottom of BH1, whereas we stopped the drilling in $\mathrm{BH} 2$ as soon as reached the bed.

After drilling was completed, water-pressure sensors (Geokon 4500S and HOBO U20) were installed in the two boreholes to measure the respective water levels. The measurements showed that the water levels in BH1 and $\mathrm{BH} 2$ correlated with one another. They fluctuated in a diurnal manner within a level between $425-460 \mathrm{~m}$ from the bed, which corresponded to more than $90 \%$ of the ice flotation level at the site. The pressure variations were correlated to surface flow speed and air temperature, implying that our hypothesis was correct. Detailed analyses of the water level variations together with ice flow speed and air temperature data will be presented elsewhere.

\section{Conclusion}

A hot-water drilling technique was employed to drill through Glaciar Perito Moreno, a freshwater calving glacier in the Southern Patagonia Icefield, for subglacial observations. We drilled two boreholes to the glacier bed at $4.7 \mathrm{~km}$ from the terminus. The drilling revealed the ice thickness at the drilling site to be $515 \pm 5 \mathrm{~m}$. The completion of the drilling to the bed was clearly detected by changes in the weight of the hose hanging in the boreholes. Water in the boreholes drained before the drilling reached the bed, indicating the existence of an englacial drainage system. According to inspections of hot water nozzles after the drilling, the glacier is probably underlain by unconsolidated sediments and gravels. The water level in boreholes after the drilling was more than $90 \%$ of the ice flotation level, which strongly suggests that ice flow of Glaciar Perito Moreno is influenced by a high subglacial water pressure and its variations.

In order to drill a glacier to a depth of more than $500 \mathrm{~m}$, two high-pressure hot-water machines were assembled together and a winch system was newly constructed. The drilling speed from the surface to the bed was $50 \mathrm{~m} \mathrm{~h}^{-1}$ when the system was running properly. The rates of fuel consumption were $15.71 \mathrm{hr}^{-1}$ for diesel and $3.91 \mathrm{hr}^{-1}$ for petrol.

\section{Acknowledgments}

We thank the members of GRPP (Glaciological Research Project in Patagonia) for their help in the field and for preparation of the drilling system. T. Wyder provided necessary information for the construction of the winch and T. Shiraiwa loaned us the winch drum. The drilling equipment was transported to the glacier by a helicopter operated by Gendarmeria Nacional Argentina. Hielo y Aventura S. A. offered logistic support during the field activity and Toshin S. A. organized the transport of materials in Argentina. Kärcher Inc., Bridgestone Co. and Nakamura Service Co. Ltd. assisted in the construction of the drilling system. The hose-stretching experiment carried out by Bridgestone Co. is greatly appreciated. S. Tsutaki and S. Matoba helped with preparation and shipment of the drilling equipment. We thank an anonymous referee for helpful comments and the scientific editor S. Matoba for handling the paper. The English was corrected by S. Braun-Clarke. This research was funded by the Japanese Ministry of Education, Science, Sports and Culture, Grant-in-Aid for Scientific Research (A), 18251002, 2006-2009 and by a funding program of the Institute of Low Temperature Science. This support is gratefully acknowledged.

\section{References}

Aniya, M. (1999): Recent glacier variations of the Hielos Patagónicos, South America, and their contribution to sealevel change. Arctic, Antarctic, and Alpine Research, 31 (2), 165-173. 
Aniya, M. and Skvarca, P. (1992): Characteristics and variations of Upsala and Moreno glaciers, southern Patagonia. Bulletin of Glaciological Research, 10, 39-53.

Aniya, M., Sato, H., Naruse, R., Skvarca, P. and Casassa, G. (1997): Recent glacier variations in the Southern Patagonia Icefield, South America. Arctic and Alpine Research, 29 (1), 1-12.

Bindschadler, R. (1983): The importance of pressurized subglacial water in separation and sliding at the glacier bed. Journal of Glaciology., 29 (101), 3-19.

Ciappa A., Pietranera, L. and Battazza, F. (2010): Perito Moreno Glacier (Argentina) flow estimation by COSMO SkyMed sequence of high-resolution SAR-X imagery. Remote Sensing of Environment, 114 (9), 2088-2096.

Floricioiu, D., Eineder, M., Rott, H. and Nagler, T. (2008): Velocities of major outlet glaciers of the Patagonia Icefield observed by TerraSAR-X. Proceedings of IEEE International Geoscience and Remote Sensing Symposium 2008 in Boston U.S., IV, 347-350.

Michel, R. and Rignot, E. (1999): Flow of Glaciar Moreno, Argentina, from repeat-pass Shuttle Imaging Radar images: comparison of the phase correlation method with radar interferometry. Journal of Glaciology, 149 (45), 93100.

Naruse, R., Skvarca, P., Kadota, T. and Koizumi, K. (1992): Flow of Upsala and Moreno glaciers, southern Patagonia. Bulletin of Glacier Research, 10, 55-62.

Naruse, R., Skvarca, P., Satow, K., Takeuchi, Y. and Nishida, K. (1995): Thickness change and short-tem flow variation of Moreno Glacier, Patagonia. Bulletin of Glacier Research, 13, 21-28.

Rignot, E., Rivera, A. and Casassa, G. (2003): Contribution of the Patagonia Ice fields of South America to sea level rize. Science, 302, 434-437.

Rivera, A., Benham, T., Casassa, G., Bamber, J. and Dowdeswell, J. A. (2007): Ice elevation and areal changes of glaciers from the Northern Patagonia Icefield, Chile, Global and Planetary Change, 59, 126-137.

Rott, H., Suefer, M., Siegel, A., Skvarca, P. and Eckstaller, A. (1998): Mass fluxes and dynamics of Moreno Glacier, Southern Patagonia Icefield. Geophysical Research Letters, 25 (9), 1407-1410.

Skvarca, P. and Naruse, R. (1997): Dynamic behavior of Gla- ciar Perito Moreno, southern Patagonia. Annals of Glaciology, 24, 268-271.

Skvarca, P., Satow, K., Naruse, R. and Leiva, J. C. (1995): Recent thinning, retreat and flow of Upsala Glacier, Patagonia. Bulletin of Glacier Research, 13, 11-20.

Stuefer, M. (1999): Investigations on mass balance and dynamics of Moreno Glacier based on field measurements and satellite imagery. PhD thesis, University of Innsbruck.

Stuefer, M., Rott, H. and Skvarca, P. (2007): Glaciar Perito Moreno, Patagonia: Climate sensitivities and glacier characteristics preceding the 2003/04 and 2005/06 damming events. Journal of Glaciology, 53 (180), 3-16.

Sugiyama, S. and Gudmundsson, G. H. (2004): Short-term variations in glacier flow controlled by subglacial water pressure at Lauteraargletscher, Bernese Alps, Switzerland. Journal of Glaciology, 50 (170), 353-362.

Sugiyama, S., Tsutaki, S., Naito, N., Enomoto, H. and Skvarca, P. (2009): Diurnal flow speed variations in Perito Moreno Glacier, Patagonia. Proceedings of JSSI \& JSSE Joint Conference on Snow and Ice Research 2009 in Sapporo, 166.

Sugiyama, S., Tsutaki, S., Nishimura, D., Blatter, H., Bauder, A. and Funk, M. (2008): Hot water drilling and glaciological observations at the terminal part of Rhonegletscher, Switzerland in 2007. Bulletin of Glaciological Research, 26, 41-47.

Truffer, M. and Iken, A. (1998): The sliding velocity over a sinusoidal bed at high water pressure. Journal of Glaciology, 44 (147), 379-382.

Tsutaki, S. and Sugiyama, S. (2009): Development of a hot water drilling system for subglacial and englacial measurements. Bulletin of Glaciological Research, 27, 7-14.

Warren, C. and Aniya, M. (1999): The calving glaciers of southern South America. Global and Planetary Change, 22, 59-77.

Warren, C., Greene, D. R. and Glasser, N. F. (1995a): Glacier Upsala, Patagonia: rapid calving retreat in fresh water. Annals of Glaciology, 21, 311-316.

Warren, C., Greene, D. R. and Glasser, N. F. (1995b): Characteristics of tide-water calving at Glacier San Rafael, Chile. Journal of Glaciology, 41 (138), 273-289. 